by James G. Gehling ${ }^{1}$ and Mary L. Droser ${ }^{2}$

\title{
Ediacaran stratigraphy and the biota of the Adelaide Geosyncline, South Australia
}

\author{
${ }^{1}$ South Australian Museum, North Terrace, Adelaide, SA 5000, Australia. E-mail: jim.gehling@samuseum.sa.gov.au \\ ${ }^{2}$ Department of Earth Sciences, University of California, Riverside, CA 92521, USA. E-mail: Mary.Droser@ucr.edu
}

The Neoproterozoic and Cambrian sequences of the Mount Lofty and Flinders ranges of South Australia record a crucial interval in the evolution of life and environments on Earth. This paper summarises the key characteristics of the Ediacaran succession of the Adelaide Geosyncline. Recent interest in the Neoproterozoic and Cambrian successions on all continents has been driven by a quest to better understand the causes and effects of the size revolution that saw the advent of multicellular organisms in the ocean. The principal role of the Neoproterozoic Subcommission has been to determine unique time boundaries that reflect evolutionary changes in the Earth system. Utilisation of a combination of geochemical, paleobiological and stratigraphic events, to offset the limitations of the Neoproterozoic paleontological record, is required to bracket this interval of Earth history. Fossils of the Cryogenian, Ediacaran and Cambrian document a series of unexpected quantum leaps in the size and diversity of life.

\section{Introduction}

The folded Neoproterozoic and early Cambrian successions of the Mt Lofty and Flinders Ranges in South Australia form a continuous N-S-trending belt from Kangaroo Island in the $\mathrm{S}$ to more than $600 \mathrm{~km} \mathrm{~N}$ and NE into the interior of the continent (Figure 1). Much of this succession is correlative with intracratonic Amadeus and Officer basins of central Australia. Plate reconstructions suggest continuations into the Ross Orogen of Antarctica. To the W the succession thins rapidly across the meridional Torrens Hinge Zone. Here some Adelaidean formations lap onto the Stuart Shelf, a platform with an undeformed, flat-lying succession of Neoproterozoic and Mesoproterozoic sediments and volcanics, underlain by Paleoproterozoic and Archaean metasediments and intrusives of the Gawler Craton.

Evidence of fault-controlled sedimentation on the margins and within the basin led von der Borch (1980) to propose the phrase “Adelaide Rift Belt", or "aulacogen" (Rutland, 1973), while others have used "Adelaide Fold Belt' (Scheibner, 1973; Plummer, 1990; Mancktelow, 1981). The historical usage of "Adelaide Geosyncline"
(Sprigg, 1952; Thomson, 1969, 1970) does not adequately describe the combination of passive margin and rift-based basin, but it does acknowledge the tectonics involved in accumulation of $>20 \mathrm{~km}$ of strata, in 300 Myr (Preiss, 1987; Williams et al., 2008). Preiss (2000) subdivided the successions into the Warrina, Heysen and Moralana supergroups. These record, in turn, at least three phases of rifting during the break up of Rodinia and the Sturt glaciation, followed by evolution of the Centralian Superbasin, and the Delamerian Orogeny with rifting E and SE of the Adelaide Geosyncline in the Cambrian.

Diapiric intrusions of massive and flow-banded carbonate cemented breccias with disorganised megaclasts of sedimentary and igneous rocks occur in the cores of anticlines and as apophyses along fault systems throughout the Flinders Ranges (Preiss, 1985). Diapiric breccias appear to be sourced from the Callanna Group, the basal succession of sedimentary strata in the Adelaide Geosyncline (Figure 2). Where outcropping, these carbonates, siliciclastics and volcanics show evidence of intercalated shallow marine, evaporitic and terrestrial sedimentation that accompanied the early rifting stage in the evolution of the Adelaide Geosyncline.

\section{Neoproterozoic Stratigraphy and Paleontology}

The Heysen Supergroup (Figure 2), consisting of the Umberatana and Wilpena groups, records the mid to late Cryogenian Sturt and Elatina glaciations (Preiss et al., 2011; Williams et al., 2008, 2011) succeeded by the Ediacaran intermittent return to warmer climates and the rise of multicellular organisms in the Ediacara biota. The base of the Cryogenian has yet to be defined.

\section{Heysen Supergroup}

This supergroup encompasses the entire succession in the central Flinders Ranges other than the diapiric rocks sourced from the base of the underlying Warrina Supergroup (Preiss, 1985, 1993). In the central Flinders Ranges the $4.5 \mathrm{~km}$ thick Umberatana Group encompasses the two main phases of glacial deposition (see Thomas et al., 2012). The carbonaceous, calcareous and pyritic Tindelpina Shale Member, of the interglacial Tapley Hill Formation, caps the Fe-rich diamictite and tillite formations of the Sturt glaciation. The upper Cryogenian glacials of the Elatina Formation are truncated by the Nuccaleena Formation at the base of the Wilpena Group and the Ediacaran System. 




Figure 1 Location map of the Adelaide Geosyncline and geological provinces in South Australia, with distribution of the late Ediacaran Pound Subgroup in the central Flinders Ranges.

for up to $50 \mathrm{~m}$ and NNW-SSE directed. Plummer (1979) regarded the Nuccaleena Formation as intertidal to supratidal. Allen and Hoffman (2005) interpreted "tepee" structures from correlative "cap-carbonates" as giant standing wave ripples generated by sustained wind fields in the wake of late Cryogenian glaciation. Schmidt et al. (2009) provided paleomagnetic evidence that the tepee-like structures in the Nuccaleena Formation developed during early diagenesis. However, draping of these well-oriented structures, in alternate directions across crests, suggests formation as wave structures, but exaggerated by diagenetic expansion and disruption or gravity sliding. The lack of microbial textures suggests rapid chemical sedimentation under conditions unsuited to preserving microbial activity. Calver (2000) described an upward decrease in carbonate $\delta^{13} \mathrm{C}$ values but a discordant increase in organic $\delta^{13} \mathrm{C}$ values explained as a possible consequence of continued stratification of ocean waters following deglaciation. Retallack's (2011) reinterpretation of the Nuccaleena Formation as a product of post-glacial loess deposition and soil formation requires exclusive exposure of a

\section{Global Stratotype Section and Point: Base of the Ediacaran System}

In 2004, the Global Stratotype Section and Point (GSSP) for the terminal Proterozoic was placed near the base of the Nuccaleena Formation in Enorama Creek in the central Flinders Ranges (Figure 1), thus establishing the Ediacaran System and Period (Knoll et al., 2006). As the Nuccaleena Formation has not been accurately dated, a date of c. $635 \mathrm{Ma}$ from near-correlative levels in Namibia and China is presumed for the base of the Ediacaran (Hoffmann et al., 2004; Condon et al., 2005; Zhang et al., 2005).

\section{Wilpena Group}

The Wilpena Group represents siliciclastic sedimentation that continued into the earliest Cambrian. Repeated erosional incisions followed by a rapid local rise in sea level characterise both the Ediacaran and Early Cambrian successions. The Wilpena Group (Figure 3) began with the immediate post-glacial Nuccaleena Formation 'cap carbonate' which as been correlated with post glacial 'cap carbonates' on other continents (Kennedy et al., 1998).

Regionally, the Nuccaleena Formation, which rests conformably on the Enorama Formation but with local disconformity, is an important lithological marker. It consists of pink to yellowish dolostone, with purple shale interbeds and lateral sandy facies. In many places, beds are truncated by $50-150 \mathrm{~cm}$ high "tepee" structures (see Schmidt et al., 2009, Figure 2), ramping with crests continuous carbonate source rock after glacial meltdown, which cannot be justified. Cap-carbonates, like the Nuccaleena Formation, and seeplike carbonate structures in the Seacliff Sandstone Member have been interpreted as products of destabilisation of gas-hydrates during nearequatorial deglaciation (Kennedy et al., 2001, 2008).

The Nuccaleena Formation grades into red siltstone and shale representing a maximum flooding surface at the base of the overlying Brachina Formation. In the $\mathrm{S}$ of the Adelaide Geosyncline, the Nuccaleena Formation is interbedded with the Seacliff Sandstone in a series of incised valley fill deposits (Dyson and von der Borch, 1994). Dyson (1985) reported parallel, ribbed structures resembling frond-like fossils from sandstone in the Elatina Formation in the southern Flinders Ranges. Soft sediment deformation in the host sediment creates some doubt remains about the biological origin of these structures.

The Brachina Formation is an upward shallowing and coarsening regressive sequence of siliciclastics, $>1.3 \mathrm{~km}$ thick. Rhythmically bedded laminated siltstones grade up into silty, cross-laminated finegrained sandstones. After a brief lowering of base level, the succession becomes sandier to the top where it grades into the cleaner and coarser ABC Range Quartzite (Plummer, 1990). To the N and E, the Brachina Formation represented by green-grey, finer grained Ulupa Siltstone. In coastal cliffs, $S$ of Adelaide, turbiditic facies at the base grade up into a thick section with hummocky cross-stratified sandstone. In addition to facies with ball and pillow, as evidence of soft-sediment deformation in fore-delta settings, certain facies suggest microbial sealing. Common crescentic synaeresis cracks, "Kinneyia" ripples 


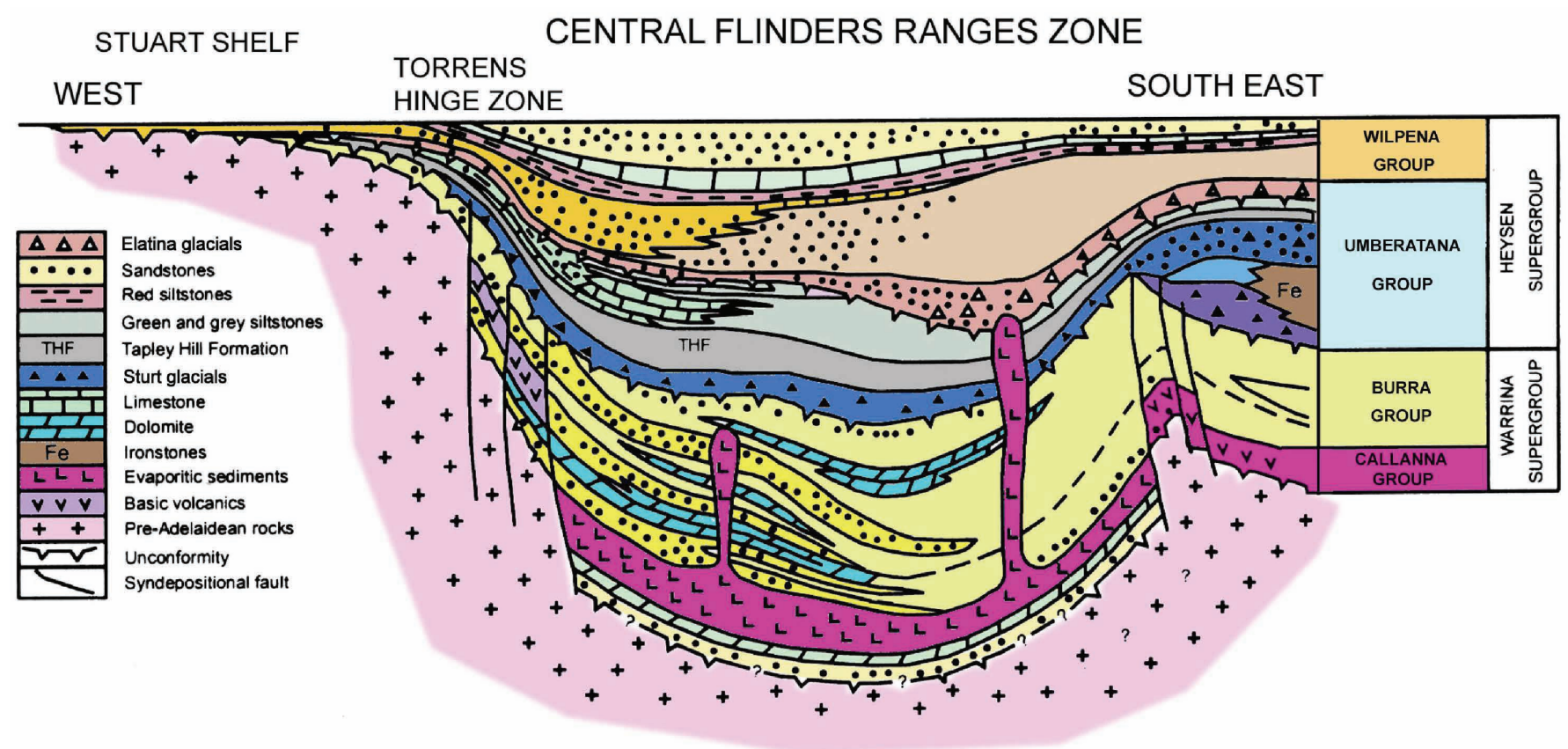

Figure 2 Schematic cross-section of the Adelaide Geosyncline through the Flinders Ranges, showing facies relationships (adapted from Lemon, 1996).

and syndepositional microfaulting record mechanical responses in microbial-bound sediment to varying degrees of wave-action, dewatering and gravity creep (see Pflüger, 1999). Pothole casts (Jenkins et al., 1981), confirm early stabilisation of soft sediment in reaction to storm events. A single specimen of an arcuate structure, Bunyerichnus dalgarnoi, originally interpreted by Glaessner (1969) as a molluscan trail, is probably a pseudofossil produced by a tethered biomat fragment. The Brachina Formation lacks body fossils.

Outcropping on the western side of the Adelaide Geosyncline, the ABC Range Formation is a medium to thickly bedded sandstone with herringbone cross bedding and desiccation cracks. From $2 \mathrm{~km}$ thick, S of Port Augusta, it thins N and S to <100 m (Plummer, 1990). The upward shoaling Brachina Formation and ABC Range Quartzite represents a highstand sequence tract where siliciclastics prograded from the Gawler Craton into the Adelaide Geosyncline with N-S tidal redistribution (Plummer, 1990).

The base of the $500 \mathrm{~m}$ thick Bunyeroo Formation, is a basinwide sequence boundary, with the Wilcolo Sandstone Member, a lowstand veneer of conglomerate and pebbly sandstone, filling local incisions into the top of the ABC Range Quartzite (Figure 3). The Bunyeroo Formation is a maroon, laminated siltstone with apparent cyclic bedding. Except for its lower member and local onlapping breccias near diapirs, it was deposited in deep water during maximum sea level. About $80 \mathrm{~m}$ above the base of the Bunyeroo Formation, a single layer of angular fragments of red, porphyritic dacite is embedded in shale and overlain by a $1-10 \mathrm{~cm}$ of graded, sand and granules with swaley cross-lamination (Figure 4a). The shale 10-20 cm above and below has been altered to a green colour. Gostin et al. (1986) interpreted this persistent layer as debris from a bolide impact. The clastic debris is comparable in lithology and $\mathrm{U}-\mathrm{Pb}$ zircon geochronology with the Mesoproterozoic Gawler Range Volcanics that lie over a large area of the Gawler Craton. Williams (1986) identified the circular Lake Acraman, $300 \mathrm{~km} \mathrm{~W}$ of the central Flinders Ranges, as the probable impact site, supported by accordant paleomagnetic data for Acraman melt rock and Bunyeroo red beds (Schmidt and Williams, 1996). The importance of this debris layer as a chronostratigraphic marker is emphasised by its tracing throughout the Flinders Ranges and in the Dey Dey Mudstone in Officer Basin drill core, $600 \mathrm{~km}$ NE of Lake Acraman (Wallace et al., 1989). The Acraman horizon in the Officer Basin marks both a negative Cisotope excursion and a transition from the older, simple leiospheredominated palynoflora (SLP) to the larger Ediacaran complex acanthomorph-dominated palynoflora (ECAP) (Arouri et al., 2000; Walter et al., 2000; Grey et al., 2003; Grey, 2005). Gostin et al. (2010) described ice rafting based on dropstones and pebble clusters both above and below the Acraman horizon, pointing to a cold midEdiacaran phase. Since Schmidt and Williams (1996) indicated a paleolatitude of c. $15^{\circ}$, the evidence for marine ice rafting offers a tentative link to the Gaskiers glaciation of 582-580 Ma (Bowring et al., 2003).

The Wonoka Formation begins with the Wearing Dolomite Member, a cupriferous, concretionary dolostone, with intraformational and edgewise conglomerates, indicates a hiatus followed by transgressive carbonates. In the central Flinders Ranges, the Wonoka Formation is an upward shallowing and coarsening sequence of 500 $\mathrm{m}$ of calcareous shale, siltstone and fine sandstone (Haines, 1990). In the $\mathrm{N}$ and $\mathrm{S}$ Flinders Ranges, canyons incised 1-1.2 km through the basal Wonoka Formation and underlying formations suggesting submarine cut and fill (von der Borch et al., 1982), a fluvial cut followed by marine fill (von der Borch et al., 1985, 1989), a Messinianstyle evaporitic drawdown of local sea level (Christie-Blick et al., 1990), and a mantle-plume uplift (Williams and Gostin, 2000). Giddings et al. (2010) suggest submarine cut and fill due to salt withdrawal tectonics (Dyson 1998, 1999, 2003; Dyson and Rowan, 2004). The stable isotope geochemistry of the Wonoka Formation features the "Wonoka-Shuram" anomaly with values of $\delta^{13} \mathrm{C}$ as low as -12 (Pell et al., 1993). These have been used to suggest a reservoir of dissolved organic carbon depleted in ${ }^{13} \mathrm{C}$ for Ediacaran oceans 


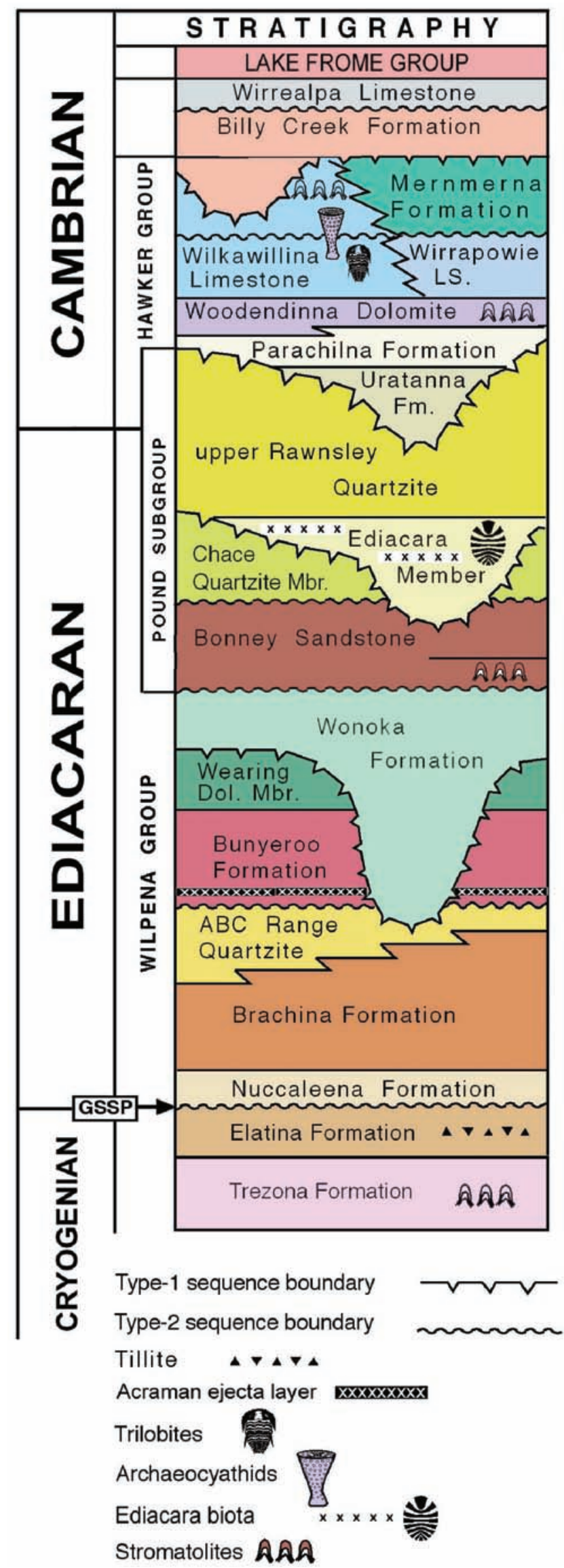

Figure 3 Depositional Sequences of the Ediacaran and Cambrian, Flinders Ranges, South Australia.
(Swanson-Hysell et al., 2010) after $580 \mathrm{Ma}$. Away from the canyons, the Wonoka Formation consists of turbidites grading up into hummocky cross stratified, silty limestone, followed by green, stylolitic, cryptomicrobial limestone alternating with sandy limestone, featuring soft-sediment deformation and intraformational breccias (Haines, 1990). The formation is capped by two parasequences of red, clayey sandstones overlain by a carbonate unit. Reid and Preiss (1999) recognised an erosive base and redefined these last cycles as part of the overlying Bonney Sandstone. The upper most carbonate is composed of black cryptalgal laminae, peloidal and oncolitic limestone, with stromatolites resembling Tungussia julia that support correlation with the Julie Formation in the Amadeus basin. From the upper Wonoka Formation, Haines (1990, 2000) described a serial, arcuate tubular fossil, Palaeopascichnus (Figure 4b) that occurs in most other Ediacara assemblages. It is the oldest identifiable member of the Ediacara biota in South Australia. Claims of other Ediacara fossils from the Wonoka Formation (Jenkins, 1983, 1995) are limited to a frondose structure, faint discs and radial arrays of spicular structures.

The Pound Subgroup, consisting of the red siliciclastics of the Bonney Sandstone disconformably overlain by the cleaner sandstones of the Rawnsley Quartzite (Figure 3), varies from $1 \mathrm{~km}$ in Wilpena Pound (Figure 1) to $>3 \mathrm{~km}$ in the NE Flinders Ranges (Gehling, 1982) and dominates the topography (Figure 5a). The red Bonney Sandstone, which is $300-400 \mathrm{~m}$ thick in the central Flinders Ranges, has transgressive shallow marine sandstone and carbonates at the base, overlain by deeper water siltstone and fine sandstone shallowing and coarsen upward as a highstand systems tract. These flat bedded and low-angle crossbedded sandstones, feature ebb and flood cycles in tidally reworked estuaries. The upper third of the formation consists of alluvial, red, poorly sorted, sandy mudstones (Gehling, 1982). Claimed occurrences of trace fossils and small discoidal body fossils in the Bonney Sandstone (Jenkins, 1995) are more likely products of wrinkled and desiccated microbial mats.

The Rawnsley Quartzite is composed of pale, medium to coarse grained, felspathic sandstone. In deeply incised sections, the Rawnsley Quartzite is reddish with Fe-stained sand grains. The light colour and indurated ridges and outcrops are likely remnants of early Cenozoic leaching and surface silicification. The disconformable base of the Rawnsley Quartzite is a low relief erosional surface marking a change, without interfingering, from the Bonney Sandstone to better sorted and lighter coloured sandstones of the Chace Quartzite Member. The Rawnsley Quartzite is a shallow marine, wave and tide reworked deltaic succession that marked a phase of uplift and erosion on the Gawler Craton (Gehling, 2000) and the onset of the Petermann Orogeny $600 \mathrm{~km}$ to the NW between the Officer and Amadeus basins (Flöttmann et al., 2004). Comprising as much as $250 \mathrm{~m}$ of the Rawnsley Quartzite, the unfossiliferous Chace Quartzite Member is a yellow weathering, pink coloured, felspathic, medium- to coarsegrained sandstone with granule trains. Sets of low angle, trough crossbedding grade up into wavy and disrupted, thinly bedded sand. This distinctive 'petee' lamination, featuring domed and disrupted, polygonal and sinuous ridges, overturning and roll-ups of sand lamination (Figure 6b), is interpreted as the product of gas-doming and desiccation of microbial bound sand laminae on tidal flats (Gehling, 1999, 2000). The near absence of silt or clay suggests that fine material bypassed these tidal flats due to aeolian sorting of alluvial sediment before it reached the ocean. Higher in the section, sand- 

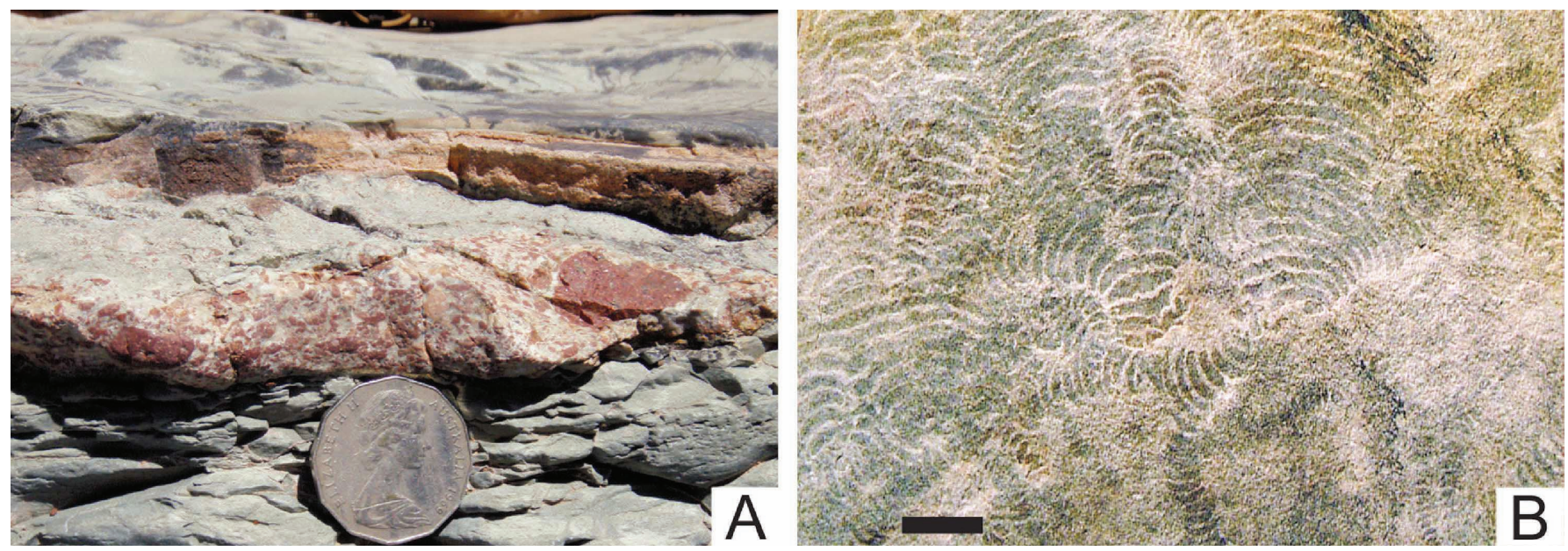

Figure 4 (A) Acraman ejecta layer, $80 \mathrm{~m}$ above base of Bunyeroo Formation, Flinders Ranges National Park; coin 3.5 cm. (B) Palaeopascichnus in the upper Wonoka Formation; scale $1 \mathrm{~cm}$.

pseudomorphs after sulfate crystals, associated with petee lamination (Figure 6a), were likely formed on supratidal sand flats (Gehling, 1999, Figure 4; Gehling, 2000).

Ediacara fossils are mainly confined to the deeper water 5350 m thick Ediacara Member (Jenkins et al., 1983; Gehling, 1982, 2000). The base of the Ediacara Member is a sequence boundary with 5-10 m deep channels and regional, 1-5 km wide, 50-250 m deep canyon incisions into the Chace Quartzite Member and, in some cases, well into the Bonney Sandstone (Figure 3). This erosional surface, traceable throughout the central Flinders Ranges, represents a marked fall in base-level. The lack of evidence of subaerial exposure and fluvial sedimentation in canyon floors indicates that they were cut and filled subaqueously. Syndepositional faulting on canyon margins, in the Chace Range and at Nilpena, suggests that the disconformable base of the Ediacara member was also a product of salt withdrawal and subsidence of mini-basins, as proposed by Dyson and Rowan (2004) at other stratigraphic levels.

The Ediacara Member commenced with a lowstand systems tract and a massive unit sandstone with basal, angular sandstone breccias filling local, $50 \mathrm{~m}$ wide and 1-20 m deep, step-sided channels within the valley incisions. In the deepest canyons, a sudden change to well laminated clayey siltstones represents a maximum flooding surface. Fossils appear on the first thin, storm sandstone beds in the upward coarsening and thickening beds in the upper half of the Ediacara Member. The Ediacara Member is a deltaic succession that prograded from the NW, filling local depocentres via incisions 50-250 m deep. The accommodation space provided by the canyons enabled a number of facies to be developed that are unknown from the canyon shoulders. On the western side of the Flinders Ranges, at Nilpena, Ediacara Conservation Park and the Mt Scott Range, the Ediacara Member is represented by a series of facies associations, the lowest of which fill smaller-scale channels and narrow canyons. While these are correlated with thicker parasequences in the main ranges, which Gehling (2000) included within the amended Ediacara Member, Jenkins and Nedin (2007) redefined these as separate members. Since these subsidiary units contain key taxa of the Ediacara biota, they represent a single generic package, unless a significant time separation can be established. Two to three parasequences cap the Ediacara Member, each with fossil horizons in the zone between fair-weather and storm wave base (Figure 5b). The top is marked by crossbedded, shore-face
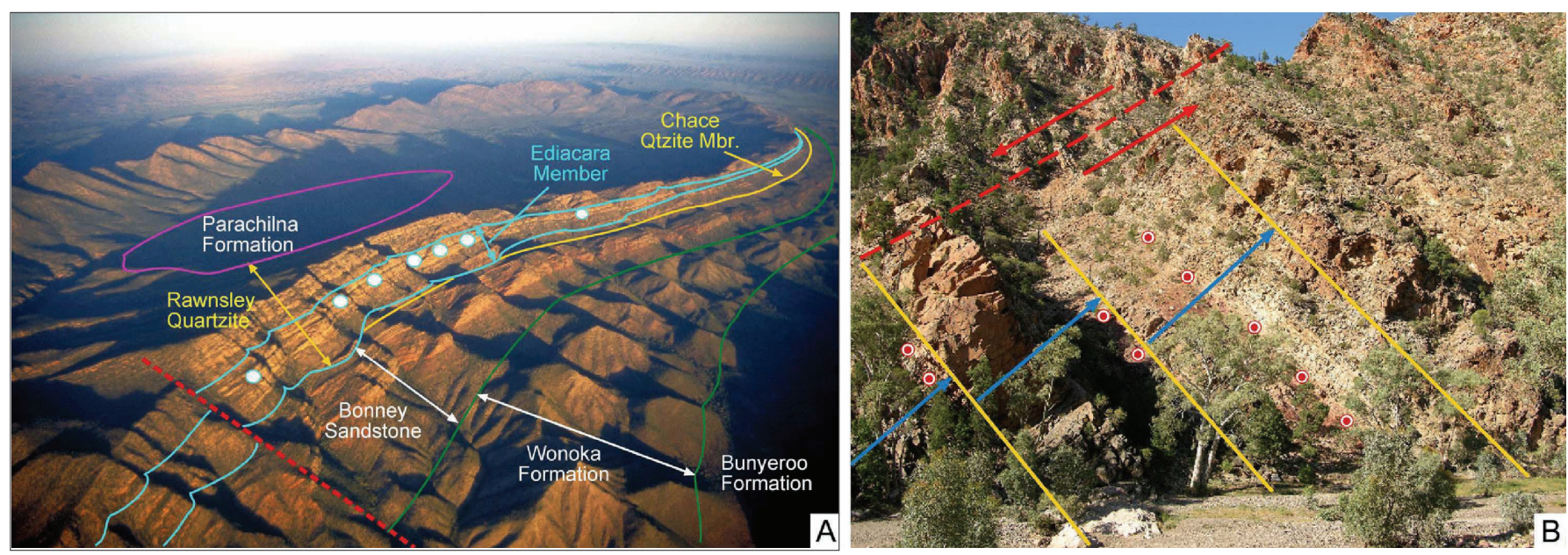

Figure 5 (A) Oblique aerial photo of Wilpena Pound, a raised synform of the Pound Subgroup capping the Ediacaran succession in the central Flinders Ranges. The fossiliferous Ediacara Member represented by discs at the base of the topographic rim. Formations age to the right. An erosional remnant of the early Cambrian Parachilna Formation remains in the centre of the synform. (B) Three upward shallowing parasequences of the Ediacara Member in Brachina Gorge, Flinders Ranges National Park, with fossil horizons represented by discs. 

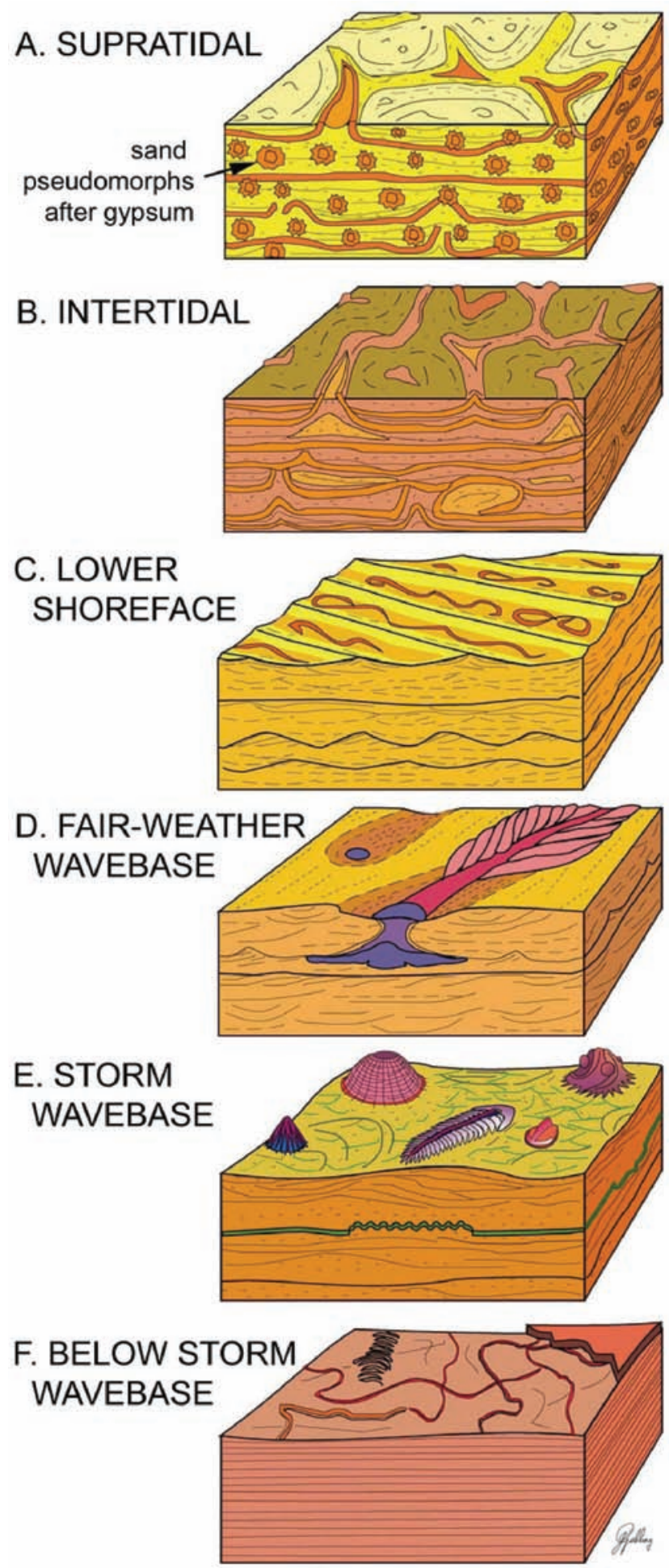

Figure 6 Facies of the Rawnsley Quartzite with depth-related associations of microbial mats and fossils. (A). Supratidal sandflats with desiccation of microbial mat bound sand lamination and sandpseudomorphs after sulfate. (B). Intertidal sandflats with domed and disrupted microbial mats. (C). Lower shore-face wave rippled sand with synaeresis cracks in microbial bound ripple troughs. (D). Fair-weather wave base with preservation of anchoring holdfasts of fronds, either flattened or torn away by storm surge. (E). Storm wave base with communities of benthic Ediacara organisms. $(F)$. Below wave base preservation below distal flows of storm surge sand. sandstone units grading into the upper $500 \mathrm{~m}$ of the Rawnsley Quartzite. The upper, Rawnsley Quartzite continues with the same association of crossbedded and petee sandstones found in the Chace Quartzite Member. Near the top of the Rawnsley Quartzite there is a transition back into wave-ripple bedded and low angle crossbedded, shore-face sandstone, with rare beds of discoidal fossils (Gehling, 2000).

\section{Ediacara Biota}

Ediacara fossils were first discovered by Sprigg $(1947,1949)$ at the Ediacara minefield on the western rim of the Flinders Ranges. There the Ediacara Member is restricted to c. $30-50 \mathrm{~m}$ of thinly bedded sandstones in a condensed and truncated Rawnsley Quartzite (Goldring and Curnow, 1967). Early study of the beds suggested beach stranding of 'jellyfish' (Glaessner and Daily, 1959; Glaessner and Wade, 1966), largely because ripple marks and synaeresis cracking of microbially bound sand were mistaken for exposure on tidal flats. Fossils of the Ediacara biota are most common on soles of thin to medium bedded sandstones from storm to fair-weather wave base (Figure 6d, e, f; Gehling, 1991, 1999). However, transported organisms occur also as deformed impressions and sand-filled casts in massive sandstone beds within canyon filling facies. Most common in lower shoreface beds, discoidal holdfasts (Figure 7b, h), with radial and concentric characters, originally named Cyclomedusa, Ediacaria, Medusinites etc. (Sprigg, 1947, 1949; Wade, 1969), are now regarded as preservational states of Aspidella (Gehling et al., 2000). In most cases they represent as attached, bulbous holdfasts of frond-like organisms (Figure 7b), where the frond has been torn off or decayed before preservation, leaving a stem-like impression, escape marks or a ghost of a frond on the opposite side of the bed (Tarhan et al., 2010). Charniodiscus (Figure 7a), the most common frondose form, resembles pennatulid soft corals in that the branches bear serial, polyp-like subdivisions. Although widespread in deep and shallow marine and environments (Narbonne, 2005), their phylogenetic affiliations remain uncertain.

Helminthoidichnites, groove and levee traces, were made by tiny motile benthic organisms too small to be recognised as external moulds (Droser et al., 2005). Gehling et al. (2005) interpreted burial contraction marks, bedding plane distribution and serial resting traces made by Dickinsonia (Figure 71) and Yorgia (Figure 7k), as evidence of muscularity, tactophobic behaviour, and direct absorption feeding on benthic mats, made by of motile, bilaterian-grade organisms. The fan-shaped sets of radular scratch marks associated with Kimberella (Figure $7 \mathrm{~s}, \mathrm{t}$ ) suggest affinities with molluscan grade organisms (Gehling et al., 2005).

Taphonomy of fossils of the Ediacara biota is a vital prerequisite to assessment of their paleobiology and paleoecology (Wade, 1968; Gehling et al., 2005). Preservation of moulds of soft-bodied organisms on bed bases resulted from smothering of microbial mats by stormsand surges strong enough to orient some frondose fossils, but not so erosive as to have stripped off unattached benthic organisms. Bacterial decay and reduction of $\mathrm{Fe}$ and sulfate produced pyritic death masks in a sole veneer that enabled coherent external moulds to form (Gehling, 1999; Gehling et al. 2005). The finest preservation of body fossils generally coincides with "textured organic surfaces", suggesting a mature mat community involving bacterial films, dead organisms and sometimes, close packed benthic organisms (Droser et al., 2006; Gehling and Droser, 2009). 

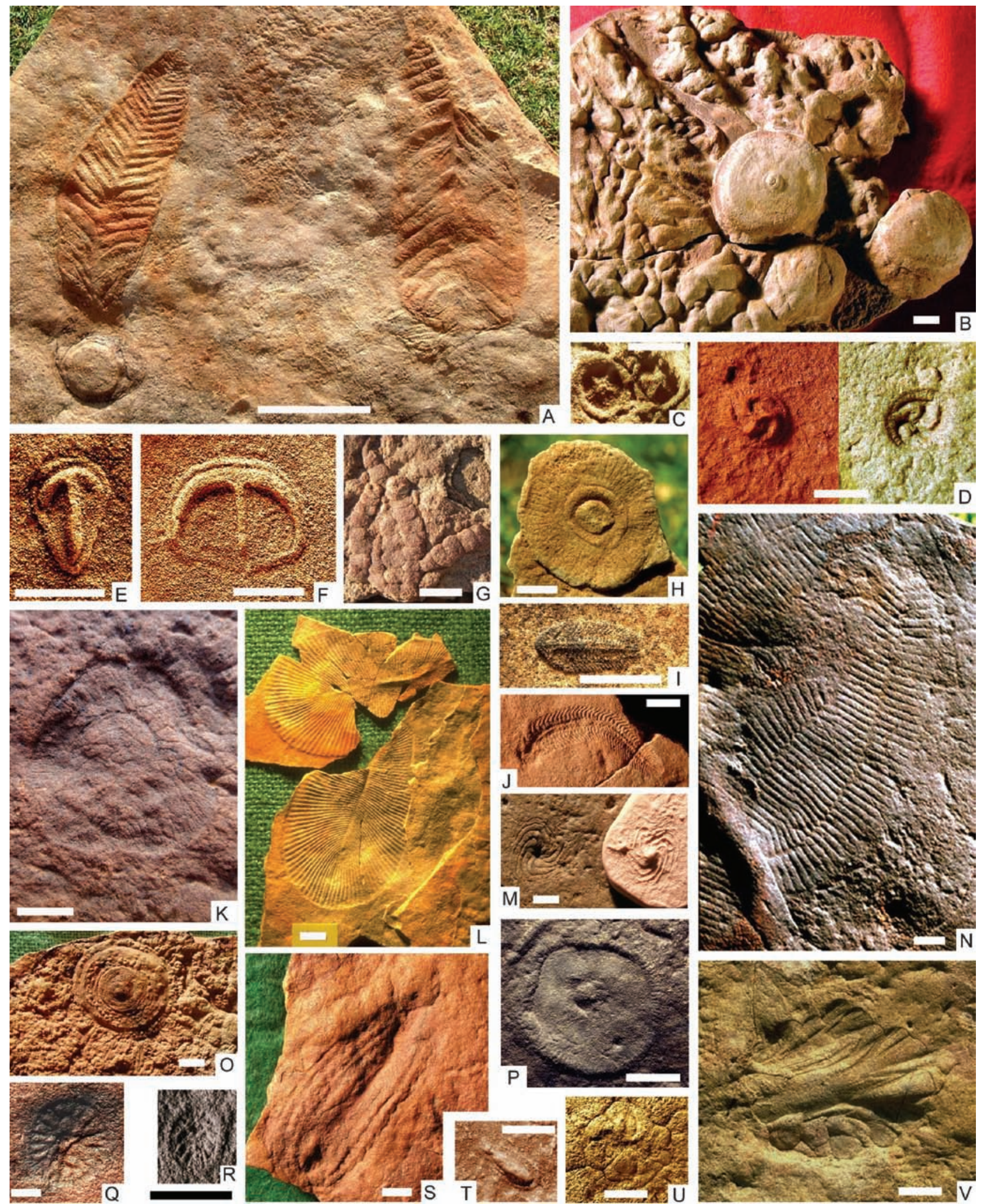

Figure 7 Fossils of the Ediacara biota, Ediacara Member, Rawnsley Quartzite, central Flinders Ranges. (A). Charniodiscus arboreus. (B). Aspidella with stalk, with load casts. $(C)$. Arkarua. (D). Tribrachidium, rubber cast and external mould. (E-F). Parvancorina, rubber casts. $(G)$. Funisia. $(H)$. Aspidella (Cyclomedusa radiata). (I). Spriggina ovata. $(J)$. Spriggina floundersi. $(K)$. Yorgia. $(L)$. Dickinsonia costata, part and counterpart. (M). Eoandromeda, natural cast and rubber mould. (N). Phyllozoon. (O). Eoporpita. (P). Palaeophragmodictya with spicule impressions. $(Q)$. Rugoconites. $(R)$. Praecambridium. $(S)$. Kimberella (holotype). (T). Kimberella with proboscis, rubber cast. (U). Conomedusites. (V). Inaria (holotype). Scale bars $1 \mathrm{~cm}$, except $(A)$ where it is $10 \mathrm{~cm}$. 
Narbonne (2005) assessed the taphonomic, environmental and age constraints of all known assemblages of the Ediacara biota. However, regional distinctions between assemblages are now less distinct. Serial excavation of fossil beds has revealed that paleoenvironments were as strong an influence on the taxonomic composition of preserved assemblages as is their stratigraphic position. Typically, fossiliferous beds are dominated by one taxon, sometimes in very large numbers. Droser and Gehling (2008) described entire bedding surfaces covered with matted specimens of the chambered, tubular animal, Funisia (Figure 7g). Local comparisons show that distinct sedimentary facies correlate with taxa present. Diverse assemblages of Ediacara fossils in the Flinders Ranges include many elements of the Mistaken Point and the Nama assemblages of Waggoner (2003). Many smaller taxa are preserved only as external moulds on sole surfaces. Most discoidal and frondose taxa are preserved in positive hyporelief (Figure 7). These contrasting preservational modes and different body plans suggest Ediacaran phyletic divergence (Gehling 1991) arguing against of claims that most Ediacara taxa represent a single extinct clade (Seilacher, 1984, 1989, 1992; Brasier and Antcliffe, 2004, 2009). Globally, most assemblages of the Ediacara biota have at least some taxa in common. For example, although Eoandromeda (Figure 7m), a clockwise spiraling, eight-armed disc, and the close-packed discs of Nemiana, are the only taxa common to both China and South Australia (Zhu et al., 2008), most taxa of the White Sea assemblage are common to South Australia (Gehling et al., 2005). However, similar fossil assemblages, on widely divergent continental fragments in the Ediacaran, are not explained by the present distribution of the source rocks alone (Wagoner, 2003).

\section{Basal Cambrian Stratigraphy}

The earliest Cambrian stratigraphy of South Australia (Jago et al., 2012) continues the late Ediacaran sedimentary character with siliciclastic units at its base. In the northern Flinders Ranges (Figure 3) the Uratanna Formation is a shallowing upward, incision-fill succession, up to $400 \mathrm{~m}$ thick (Mount and McDonald, 1992; Jensen et al., 1998), resembling the Ediacara Member. In the Mount Scott Range, the Uratanna Formation cuts down into the Rawnsley Quartzite to the thinned Ediacara Member (Daily, 1973), and passes up into the shallow marine, shore-face and lagoonal Parachilna Formation, which everywhere onlaps the Rawnsley Quartzite. Regionally, the EdiacaranCambrian boundary is marked by un-burrowed sandstone of the Rawnsley Quartzite disconformably overlain by the Parachilna Formation with dense accumulations of Diplocraterion burrows and, further up section, diverse trace fossils including Plagiogmus and small helcionellids (Zang et al., 2007).

In a valley-fill succession, $40 \mathrm{~km}$ E of Leigh Creek, Treptichnus pedum and Phycodes coronatum first appear in sandy facies more than $200 \mathrm{~m}$ above the base of the Uratanna Formation (Jensen et al., 1998). Considering the facies problem, the base of the Cambrian succession is locally mapped at the basal disconformity (Nedin and Jenkins, 1991). The subtidal, storm bedded sandstones in the upper part of this succession contain a diverse Cambrian trace fossil assemblage together with a single horizon of frond-like fossils of Ediacaran aspect (Jensen et al., 1998). Daily (1972) described Rusophycus burrows from this sandy facies of the Uratanna Formation in the Mundy Waters Syncline, that demonstrate the existence of arthropods with paired burrowing appendages in the earliest Cambrian, well before the first mineralised trilobites. Sabellidites cambriensis and acritarchs of the Redkinia-Cymatiosphaera Assemblage Zone in the Uratanna Formation (Mount and McDonald, 1992; Zang et al., 2007) indicate a Nemakit-Daldyn age.

\section{Summary}

The Ediacaran succession in the Flinders Ranges preserves the transition from a biological system of small organic walled eukaryotic and prokaryotic microfossils that were responsible for stromatolitic reefs and raised free oxygen levels. The Ediacaran marked a series of biological changes in the wake of Cryogenian ice ages that precipitated the rise of multicellular life. In the Flinders Ranges, the separation between Ediacaran and early Cambrian siliciclastic sequences is defined by the onset of deep burrowing that is closely associated with the first small shelly fossils. This indicates an ecological revolution that extinguished many of the life-styles of the Ediacara biota and ushered in the Phanerozoic. The behavioral evolution that produced deep burrowing, whether in response to predation or to access buried organic matter, effectively destroyed the microbial mat "film" that recorded impressions of soft-bodied organisms in the Ediacaran Period.

\section{Acknowledgements}

Support has been provided from Australian Research Council Discovery grant (DP0453393) and National Science Foundation grant (EAR-0074021). George Williams and Wolfgang Preiss provided valuable reviews.

\section{References}

Allen, P.A. and Hoffman, P.F., 2005, Extreme winds and waves in the aftermath of a Neoproerozoic glaciation: Nature, v. 433, pp. 123-127.

Arouri, K., Conaghan, P.J., Walter, M.R., Bischoff, G.C.O. and Grey, K., 2000, Reconnaissance sedimentology and hydrocarbon biomarkers of Ediacarian microbial mats and acritarchs, lower Ungoolya Group, Officer basin: Precambrian Research, v.100, pp. 235-280.

Bowring, S.A., Myrow, P., Landing, E., Ramezani, J., Condon, D. and Hoffmann, K.H., 2003, Geochronological constraints on Neoproerozoic glaciations and the rise of metazoans. Geological Society of America, Abstracts with Programs, v. 35, no. 6, p. 517.

Brasier, M.D. and Antcliffe, J., 2004. Decoding the Ediacaran enigma: Science. v. 305, pp. 1115-1117.

Brasier, M.D. and Antcliffe, J., 2009, Evolutionary relationships within the Avalonian Ediacara biota: new insights from laser analysis: Geological Society of London, Journal, v. 166, pp. 363-384.

Calver, C.R., 2000, Isotope stratigraphy of the Ediacaran (Neoproterozoic III) of the Adelaide Rift Complex, Australia, and the overprint of water column stratification: Precambrian Research, v. 100, pp. 121-150.

Christie-Blick, N., von der Borch, C.C. and DiBona, P.A., 1990, Working hypothesis for origin of the Wonoka Canyons (Neoproterozoic), South Australia: American Journal of Science, v. 290-A, pp. 295-332.

Condon, D. Zhu, M., Bowring, S., Wang, W., Yang, A. and Jin, Y., 2005, U$\mathrm{Pb}$ ages from the Neoproterozoic Doushantuo Formation, China: Science, v. 308 , pp. $95-98$.

Daily, B., 1972, The base of the Cambrian and the first Cambrian faunas. Centre for Precambrian Research: University of Adelaide, Special Paper, v. 1 , pp. 13-41.

Daily, B., 1973, Discovery and significance of basal Cambrian Uratanna Formation, Mt Scott Range, Flinders Ranges, South Australia: Search, v. 4 , pp. $202-205$. 
Droser, M.L. and Gehling, J.G., 2008, Reproduction and synchronous aggregate growth in a new Ediacaran tubular organism: Science, v. 319, pp. 1660-1662.

Droser, M.L., Gehling, J.G. and Jensen, S.R., 2005, Ediacaran trace fossils: true and false, in Briggs, D.E.G. (ed), Evolving Form and Function: Fossils and Development: Proceedings of Seilacher Symposium, New Haven: Peabody Museum of Natural History, Yale University, pp. $125-138$.

Droser, M. L., Gehling, J.G. and Jensen, S.R., 2006, Assemblage palaeoecology of the Ediacara biota: The unabridged edition? Palaeogeography, Palaeoclimatology, Palaeoecology, v. 232, pp. 131-147.

Dyson, I.A., 1985, Frond-like fossils from the base of the late Precambrian Wilpena Group, South Australia: Nature, v. 318, pp. 283-285.

Dyson, I.A., 1998, The 'Christmas tree diapir' and salt glacier at Pinda Springs, central Flinders Ranges: MESA Journal, v. 10, pp. 34-38.

Dyson, I.A., 1999, The Beltana Diapir - a salt withdrawal minibasin in the northern Flinders Ranges: MESA Journal, v. 15, pp. 40-46.

Dyson, I.A., 2003, A new model for the Wonoka canyons in the Adelaide Geosyncline: MESA Journal, v. 31, pp. 49-58.

Dyson, I.A. and Rowan, M.G., 2004, Geology of a welded diapir and flanking mini-basins in the Flinders Ranges of South Australia: GCSSEPM $24^{\text {th }}$ Annual Bob F. Perkins Research Conference, pp. 69-89.

Dyson, I.A. and von der Borch, C.C., 1994, Sequence stratigraphy of an incised-valley fill: the Neoproterozoic Seacliff Sandstone, Adelaide Geosyncline, South Australia: SEPM, Special Publication, v. 51, pp. 209222.

Flöttmann, T., Hand, M., Close, D., Edgoose, C. and Scrimgeour, I., 2004, Thrust tectonic styles of the intracratonic Petermann and Alice Springs Orogenies, Central Australia, in McClay, K., (ed), Thrust Tectonics and Hydrocarbon Systems: American Association of Petroleum Geologists, Memoir, v. 82, pp. 538-557.

Gehling, J.G., 1982, The sedimentology and stratigraphy of the late Precambrian Pound Subgroup, central Flinders Ranges, South Australia: MSc thesis, University of Adelaide (unpublished).

Gehling, J.G., 1991, The case for Ediacaran fossil roots to the metazoan tree: Journal of Geological Society of India, Memoir, v. 20, pp. 181-224.

Gehling, J.G., 1999, Microbial mats in terminal Proterozoic siliciclastics: Ediacaran death masks: Palaios, v. 14, pp. 40-57.

Gehling, J.G., 2000, Sequence stratigraphic context of the Ediacara Member, Rawnsley Quartzite, South Australia: a taphonomic window into the Neoproterozoic biosphere: Precambrian Research, v. 100, pp. 65-95.

Gehling, J. G. and Droser, M. L., 2009, Textured organic surfaces associated with the Ediacara biota in South Australia: Earth Science Reviews, v. 96, pp. 196-206.

Gehling, J.G., Narbonne, G.M. and Anderson M.A., 2000, The first named Ediacaran body fossil, Aspidella terranovica: Palaeontology, v. 43, pp. 427-456.

Gehling, J. G., Droser, M. L., Jensen, S. R. and Runnegar, B.N., 2005, Ediacaran organisms: relating form and function, in Briggs, D.E.G. (ed), Evolving Form and Function: Fossils and Development: Proceedings of Adolf Seilacher Symposium. New Haven: Peabody Museum of Natural History, Yale University. pp. 43-67.

Giddings, J.A., Wallace, M.W., Haines, P.W. and Mornane, K., 2010, Submarine origin for the Neoproterozoic Wonoka canyons, South Australia: Sedimentary Geology, v. 223, pp. 35-50.

Glaessner, M.F., 1969, Trace fossils from the Precambrian and basal Cambrian: Lethaia, v. 2, pp. 368-393.

Glaessner, M.F. and Daily, B., 1959, The geology and late Precambrian fauna of the Ediacara Fossil Reserve: South Australian Museum, Records, v. 13, pp. 369-401.

Glaessner, M.F. and Wade, M., 1966, The late Precambrian fossils from Ediacara, South Australia. Palaeontology, v. 9, pp. 599-628.

Goldring, R. and Curnow, C.N., 1967, The stratigraphy and facies of the Late Precambrian at Ediacara, South Australia: Geological Society of Australia, Journal, v. 14, pp. 195-214.

Gostin, V.A., Haines, P.W., Jenkins, R.J.F., Compston, W. and Williams, G.E.,
1986, Impact ejecta horizon within late Precambrian shales, Adelaide Geosyncline, South Australia: Science, v. 233, pp. 198-200.

Gostin, V.A., McKirdy, D.M., Webster, L.J. and Williams, G.E., 2010 Ediacaran ice-rafting and coeval asteroid impact, South Australia: insights into the terminal Proterozoic environment: Australian Journal of Earth Sciences, v. 57, pp. 859-869.

Grey, K., 2005, Ediacaran palynology of Australia: Association of Australasian Palaeontologists, Memoir, v. 31, pp. 1-439.

Grey, K., Walter, M.R. and Calver, C.R., 2003, Neoproterozoic biotic diversification: Snowball Earth or aftermath of the Acraman impact? Geology, v.31, pp. 459-462.

Haines, P.W., 1990, A late Proterozoic storm-dominated carbonate shelf sequence: the Wonoka Formation in the central and southern Flinders Ranges, South Australia, in Jago, J.B. and Moore, P.S. (eds), The evolution of a late Precambrian - Early Palaeozoic rift complex: the Adelaide Geosyncline: Geological Society of Australia, Special Publications, v. 16, pp. 177-198.

Haines, P.W., 2000, Problematic fossils in the late Neoproterozoic Wonoka Formation, South Australia: Precambrian Research, v. 100, pp. 97-108.

Hoffmann, K.-H., Condon, D.J., Bowring, S.A. and Crowley, J.L., 2004, $\mathrm{U}-\mathrm{Pb}$ zircon date from the Neoproterozoic Ghaub Formation, Namibia: constraints on Marinoan glaciation: Geology, v. 32, pp. 817-820.

Jago, J.B., Gehling, J.G., Paterson, J.R., Brock, G.A. and Zang, W., 2012, Cambrian stratigraphy and biostratigraphy of the Flinders Ranges and the north coast of Kangaroo Island, South Australia; Episodes (this volume).

Jenkins, R.J.F., 1983, Interpreting the oldest fossil cnidarians, in Proceedings of the $4^{\text {th }}$ International Symposium on Fossil Cnidaria: Palaeontographica Americana, v. 54, pp. 95-104.

Jenkins, R.J.F., 1995, The problems and potential of using animal fossils and trace fossils in terminal Proterozoic biostratigraphy: Precambrian Research, v. 73, pp. 51-69.

Jenkins, R.J.F. and Nedin, C., 2007, The provenance and palaeobiology of a new multi-vaned, chambered frondose organism from the Ediacaran (later Neoproterozoic) of South Australia, in Vickers-Rich, P. and Komarower, P. (eds), The Rise and Fall of the Ediacaran Biota: Geological Society of London, Special Publications, v. 286, pp. 195-222.

Jenkins, R.J.F., Plummer, P.S. and Moriarty, K., 1981, Late Precambrian pseudofossils from the Flinders Ranges, South Australia: Royal Society of South Australia, Transactions, v. 105, pp. 67-83

Jenkins, R.J.F., Ford, C.H. and Gehling, J.G., 1983, The Ediacara Member of the Rawnsley Quartzite: the context of the Ediacara assemblage (late Precambrian, Flinders Ranges): Geological Society of Australia, Journal, v. 30, pp. 101-119.

Jensen, S., Gehling, J.G. and Droser, M.L., 1998, Ediacara-type fossils in Cambrian sediments: Nature, v. 393, pp. 567-569.

Kennedy, M.J., Runnegar, B., Prave, A.R., Hoffmann, K.H. and Arthur, M.A., 1998, Two or four Neoproterozoic glaciations? Geology, v. 26, pp. 10591063.

Kennedy, M.J., Christie-Blick, N. and Sohl, L., 2001, Are Proterozoic cap carbonates and isotopic excursions a record of gas hydrate destabilization following Earth's coldest intervals? Geology, v. 29, pp. 443-446.

Kennedy, M.J., Mrofka, D. and von der Borch, C., 2008, Snowball Earth termination by destabilization of equatorial permafrost methane clathrate: Nature, v. 453, pp. 642-645.

Knoll, A.H, Walter, M.R., Narbonne, G.M. and Christie-Blick, N., 2006, The Ediacaran Period: a new addition to the geologic scale. Lethaia, v. 39, pp. 13-30.

Mancktelow, N.S., 1981, Variation in fold axis geometry and slaty cleavage microfabrics associated with a major fold arc, Fleurieu Peninsula, South Australia: Geological Society of Australia, Journal, v. 28, pp. 1-12.

Mount, J.F. and McDonald, C., 1992, Influence of changes in climate, sea level and depositional systems on the fossil record of the NeoproterozoicEarly Cambrian metazoan radiation, Australia: Geology, v. 20, pp. 10311034.

Narbonne, G.M., 2005, The Ediacara biota: Neoproterozoic origin of animals 
and their ecosystems: Annual Reviews of Earth and Planetary Sciences, v. 33 , pp. $13.1-13.22$.

Nedin, C. and Jenkins, R.J.F., 1991, Re-evaluation of unconformities separating the "Ediacaran" and Cambrian Systems, South Australia. Comment: Palaios, v. 6, pp. 102-105.

Pell, S.D., McKirdy, D.M., Jansyn, J. and Jenkins, R.J.F., 1993, Ediacaran carbon isotope stratigraphy of South Australia - an initial study: Royal Society of South Australia, Transactions, v. 117, pp.153-161.

Pflüger, F., 1999, Matground structures and redox facies: Palaios, v. 14, pp. 25-39.

Plummer, P.S., 1979, Note on the palaeoenvironmental significance of the Nuccaleena Formation (upper PreCambrian), central Flinders Ranges, South Australia: Royal Society of South Australia, Transactions, v. 107, pp. 171-175.

Plummer, P.S., 1990, Late Precambrian wave- to tide-dominated delta evolution in the west-central Adelaide Geosyncline, South Australia, in Jago, J.B. and Moore, P.S. (eds). The evolution of a late Precambrian Early Palaeozoic rift complex: the Adelaide Geosyncline: Geological Society of Australia, Special Publications, v. 16, pp. 164-176.

Preiss, W.V., 1985, Stratigraphy and tectonics of the Worumba Anticline and associated intrusive breccias. Geological Survey of South Australia, Bulletin, v. 52.

Preiss, W.V., 1987, The Adelaide Geosyncline - late Proterozoic stratigraphy, sedimentation, palaeontology and tectonics: Geological Survey of South Australia, Bulletin, v. 33.

Preiss, W.V., 1993, The Precambrian, in Drexel, J.F., Preiss, W.V. and Parker, A.J. (eds), The geology of South Australia, Vol. 1: South Australian Geological Survey, Bulletin, v. 54, pp. 171-204.

Preiss, W.V., 2000, The Adelaide Geosyncline of South Australia and its significance in Neoproterozoic continental reconstruction: Precambrian Research, v. 100, pp. 21-63.

Preiss, W.V., Ashley, P.M., Williams, G.E., Schmidt, P.W., Gostin, V.A. and McKirdy, D.M., 2011, The glacial succession of Sturtian age in South Australia - the Yudnamutana Subgroup, in The Geological Record of Neoproterozoic Glaciations: Geological Society of London, Memoir, v. 36, pp. 701-712.

Reid, P. and Preiss, W.V., 1999, Parachilna map sheet. Geological Survey of South Australia, Geological Atlas 1:250,000 Series, sheet SH 54-13.

Retallack, G.J., 2011, Neoproterozoic loess and limits to snowball Earth: Geological Society of London, Journal, v. 168, pp. 289-307.

Rutland, R.W.R., 1973, Tectonic evolution of the continental crust of Australia, in Tarling, D.H. and Runcorn, S.K., (eds), Continental drift, sea floor spreading and plate tectonics: implications to the earth sciences: Academic Press, London, pp. 1003-1025.

Schmidt, P.W. and Williams, G.E., 1996, Palaeomagnetism of the ejectabearing Bunyeroo Formation, late Neoproterozoic, Adelaide fold belt, and the age of the Acraman impact: Earth and Planetary Science Letters, v. 134 , pp. $347-357$.

Schmidt, P.W., Williams, G.E. and McWilliams, M.O., 2009, Palaeomagnetic and magnetic anisotropy of late Neoproterozoic strata, South Australia: Implications for palaeolatitude of late Cryogenian glaciation, cap carbonate and the Ediacaran System: Precambrian Research, v. 174, pp. $35-52$.

Scheibner, E., 1973, A plate tectonic model of the Palaeozoic tectonic history of New South Wales: Journal of the Geological Society of Australia, v. 20 , pp. $405-426$.

Seilacher, A., 1984, Late Precambrian and Early Cambrian Metazoa: Preservational or real extinctions? in Holland, H.D. and Trendall, A.F. (eds), Patterns of Change in Earth Evolution, (Dahlem Konferenzen): Springer-Verlag, Berlin, pp. 159-168.

Seilacher, A., 1989, Vendozoa: Organismic construction in the Proterozoic biosphere: Lethaia, v. 22, pp. 229-239.

Seilacher, A., 1992, Vendobionta and Psammocorallia: lost constructions of Precambrian evolution: Geological Society of London, Journal, v. 149, pp. 607-613.

Sprigg, R.C., 1947, Early Cambrian (?) jellyfishes from the Flinders Ranges,
South Australia: Royal Society of South Australia, Transactions, v. 71, pp. 212-224.

Sprigg, R.C., 1949, Early Cambrian 'jellyfishes' of Ediacara, South Australia, and Mount John, Kimberley District, Western Australia: Royal Society of South Australia, Transactions, v. 73, pp. 72-99.

Sprigg, R.C., 1952, Sedimentation in the Adelaide Geosyncline and the formation of the continental terrace, in Glaessner, M.F. and Sprigg, R.C. (eds), Sir Douglas Mawson Anniversary Volume: University of Adelaide, Adelaide, pp. 153-156.

Swanson-Hysell N.L., Rose, C.V., Calmet, C.C., Halverson, G.P., Hurtgen, M.T. and Maloof, A.C., 2010, Cryogenian glaciation and the onset of carbon-isotope decoupling: Science, v. 238, pp. 608-611.

Tarhan, L.G., Droser, M.L. and Gehling, J.G., 2010, Taphonomic controls on Ediacaran diversity: uncovering the holdfast origin of morphologically variable enigmatic structures: Palaios, v. 25, pp. 823-830.

Thomas, M., Clarke, J.D.A., Gostin, V.A., Williams, G.E. and Walter, M.R., 2012, The Flinders Ranges and surrounds: a window on astrobiology and planetary geology: Episodes (this volume).

Thomson, B.P., 1969, Precambrian basement cover: the Adelaide System, in Parkin, L.W. (ed), Handbook of South Australian Geology: Geological Survey of South Australia, pp. 21-48.

Thomson, B.P., 1970, A review of the Precambrian and lower Palaeozoic tectonics of South Australia: Royal Society of South Australia, Transactions, v. 94, pp. 193-221.

von der Borch, C.C., 1980, Evolution of the late Proterozoic to Early Palaeozoic Adelaide Foldbelt, Australia: comparisons with post-Permian rifts and passive margins: Tectonophysics, v. 70, pp. 115-134.

von der Borch, C.C., Smit, R. and Grady, A.E., 1982, Late Precambrian submarine canyons of Adelaide Geosyncline, South Australia: AAPG Bulletin, v. 66, pp. 332-347.

von der Borch, C.C, Aldam, R., Miller, D., Neuman, R., Rovira, A. and Eickhoff, K. 1985, A large-scale meandering submarine canyon: outcrop example from the late Proterozoic Adelaide Geosyncline, South Australia: Sedimentology, v. 32, pp. 507-518.

von der Borch, C.C, Aldam, R., Eickhoff, K., DiBona, P.A. and ChristieBlick, N., 1989, Late Proterozoic Patsy Springs canyon, Adelaide Geosyncline: submarine or subaerial origin? Sedimentology, v. 36, pp. 777-792.

Wade, M., 1968, Preservation of soft-bodied animals in Precambrian sandstones at Ediacara, South Australia: Lethaia, v. 1, pp. 238-267.

Wade, M., 1969, Medusae from the uppermost Precambrian or Cambrian sandstones, central Australia: Palaeontology, v. 12, pp. 351-365.

Waggoner, B., 2003, The Ediacaran Biotas in Space and Time: Integrative and Comparative Biology, v. 43, pp. 104-113.

Wallace, M.W., Gostin, V.A. and Keays, R.R., 1989, Discovery of the Acraman impact ejecta in the Officer basin and its stratigraphic significance: Australian Journal of Earth Sciences, v. 36, pp. 585-587.

Walter, M.R., Veevers, J.J., Calver, C.R., Gorjan, P. and Hill, A.C., 2000, Dating the 840-544 Ma Neoproterozoic interval by isotopes of strontium, carbon, and sulfur in seawater and some interpretive models: Precambrian Research, v. 100, pp. 371-433.

Williams, G.E., 1986, The Acraman impact structure: source of ejecta in late Precambrian shales, South Australia: Science, v. 233, pp. 200-203.

Williams, G.E. and Gostin, V.A., 2000, Mantle plume uplift in the sedimentary record: origin of kilometre-deep canyons within late Neoproterozoic successions, South Australia: Geological Society of London, Journal, v. 157 , pp. $759-768$.

Williams, G.E., Gostin, V.A., McKirdy, D.M. and Preiss, W.V., 2008, The Elatina Glaciation, late Cryogenian (Marinoan Epoch) South Australia: sedimentary facies and palaeoenvironments: Precambrian Research, v. 163 , pp. 307-331.

Williams, G.E., Gostin, V.A., McKirdy, D.M., Preiss, W.V. and Schmidt, P.W., 2011, The Elatina glaciation (late Cryogenian), South Australia, in The Geological Record of Neoproterozoic Glaciations: Geological Society of London, Memoir, v. 36, pp. 713-721.

Zhang, S. Jiang, G, Zhang, J., Song, B., Kennedy, M.J. and Christie-Blick, 
N., 2005, U-Pb sensitive high-resolution ion microprobe ages from the Doushantu Foramtion in south China: Constraints on late Neoproterozoic glaciations: Geology, v. 33, pp. 473-476.

Zang, W.L., Moczydlowska, M. and Jago, J.B., 2007, Lower Cambrian acritarch assemblage zones in South Australia and global correlation:

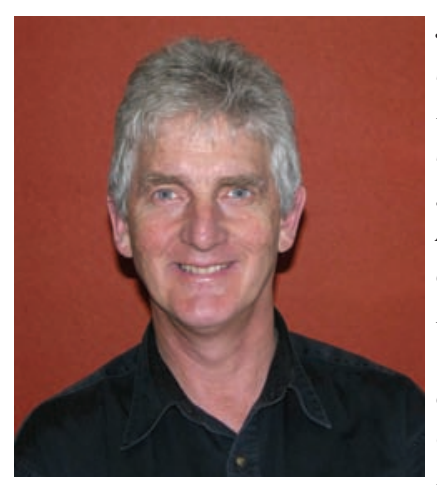

Jim Gehling is a Senior Research Scientist in Paleontology in the Earth Sciences Division of the South Australian Museum. He graduated from the University of Adelaide (BSc Hons and MSc), and from University of California, Los Angeles (PhD). His current research is on the paleobiology and palaeoenvironments of fossils of the Ediacara biota from the Flinders Range and the Early Cambrian Emu Bay biota of Kangaroo Island, South Australia. Since 2004, he has been the chairman of the Neoproterozoic Subcommission of the ICS.
Association of Australasian Palaeontologists, Memoir, v. 33, pp. 141177.

Zhu, M., Gehling, J.G., Xiao, S., Zhao, Y. and Droser, M.L., 2008, Eightarmed Ediacara fossil preserved in contrasting taphonomic windows from China and Australia: Geology, v. 36, pp. 867-870.

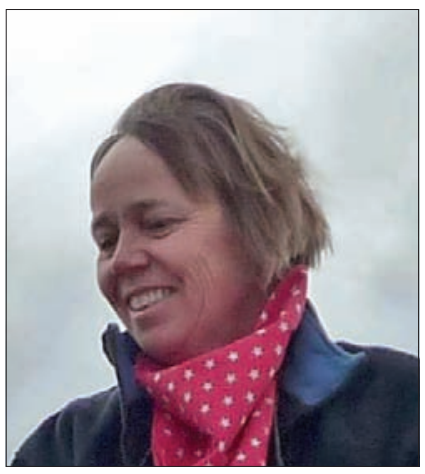

Mary Droser is an evolutionary paleoecologist at the University of California, Riverside. She gained her PhD from the University of Southern California. Her primary interests are the development of benthic communities which she approaches using the combined body fossil and trace fossil record. Her current research focuses primarily on the paleoecology and taphonomy of the Ediacara Biota. Additional interests include the development of the biological benthic boundary layer and the paleoecology and fluctuating redox conditions of ancient low oxygen communities. 